\title{
Newspapers as the first draft of history. (The NYT coverage of Nagorno- Karabakh Conflict: 1988-1991)
}

$\mathrm{S}$ erving as one of the primary sources of information, newspapers always played an important role in drafting history. Digitization of newspaper archives since the early 2000s opened tremendous opportunities for historians as well as amateur scholars. On the one side, the new opportunities facilitated research activities, but, on the other side, they unveiled new challenges, for everybody could henceforth claim to be a historian or make the slightest contribution to the history using newspaper archives as a primary source. Yet there is the question casting doubt on the reliability of newspapers articles as a primary source, and the extent to which researchers can utilize digitized archives.

While researching the coverage of Nagorno-Karabakh conflict in the American media, I tried, through the use of NYT archive collection, to provide an answer to the main research question - to what extent could newspaper archives benefit to drafting history? What are the advantages and disadvantages of such draft for historiography?

In 1988, following three years since the inception of glasnost, the perestroika entered a new dangerous phase, which could be characterized as a pre-independence period. Consequently, the present research covers a three-year pre-independence period that coincides with the outbreak of protests that later ushered two USSR republics into the NagornoKarabakh Conflict, and lasts until 1991 when those conflicting republics gained independence.

Erupted in 1988, the Nagorno-Karabakh Conflict, that heralded unrests and instability on the south-western periphery of the Soviet Union, immediately caught the attention of the US media, particularly the NYT. A series of features on the South Caucasus, also known as Transcaucasia, a remote geographical region in the Russian realms, intensified tremendously compared to the Perestroika period. In 1985, there were 16 articles either about or with reference to the region; that number increased slightly, to 17 in 1986, but faded away down to 5 in 1987. The start of the conflict turned the corresponding figures the other way up - some 203 articles were produced, a 40-fold increase from the previous year. Subsequently, since 1988 to 1991, or during the years preceding the region into independence, the number of articles about South Caucasus, including Azerbaijan, exceeded 500. Those were four crucial years prior to independence, for they played a significant role in building an independent Azerbaijan and promoting its image and standing in the eyes of the international community.

In 1988, NYT published 207 articles in which Azerbaijan was mentioned; 146 of them were analyzed for the purpose of this research, resulting in the following classification: 


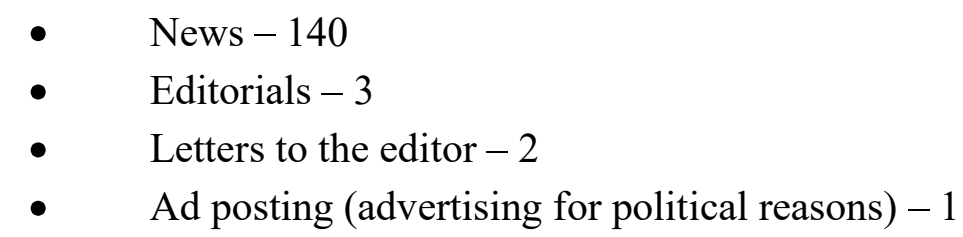

In February 1988, following the activation of the separatist movement in NagornoKarabakh, then an autonomous province of Azerbaijan, the overall situation in the country was reaching a boiling point that later escalated into a major disturbance in the South Caucasus. The imminent political crises in the southern borders of the USSR stipulated the NYT's interest for the region so much that the leading U.S. daily newspaper published two articles on the same day.

The first articles, Soviet Reports Major Unrest in Armenian Areas in South" and "A Dispute with Religious Overtones", appeared on February 24, 1988, on pages A1 and A15, respectively. The authors of both articles were the correspondents of NYT's Moscow service, P. Taubman and F. Barringer, while the primary news sources were the Izvestiya, a leading Soviet daily newspaper, and the TASS, the Soviet's top news agency. The lead paragraph provided an answer to $4 \mathrm{~W}$ out of the standard $5 \mathrm{~W}$ (When? Who? What? Where? Why?) questions: "The Soviet Union today reported major Armenian nationalist disturbances in an ethnically volatile area in the southern part of the country". 223

After one paragraph the author gives more details on "an ethnically volatile area in the southern part of the country": The press agency TASS said there had been a "breaching of public order" in the Nagorno-Karabakh Autonomous Region, the remote mountainous area within the Azerbaijan Republic near the border with Iran". 224

Further the author presents two very important segments of the news: a background and possible developments. Describing the region as "an area of arid mountains that is known for the longevity of many residents and the production of sheep, pigs, grapes and tobacco", he mentions that "it is composed of 126,000 Armenians, who are predominantly Christian, 37,000 Azerbaijanis, who are Moslem". It should be noted, however, that Nagorno-Karabakh is densely forested, and therefore cannot be described as "an area of arid mountains". While speaking about the population, the author gives more information on Armenians and ignores the ethnic Azerbaijani community: "Armenians, along with Jews and ethnic Germans, have sought to emigrate to the west in greater numbers than other Soviet national groups. More than 1,000 Armenians a month have been receiving permission to emigrate since late last year. Many have moved to the Los Angeles area, where there is a large Armenian population". 225

Regarding further possible development of the events, the journalist presented the views of Western analysts on nationalism as "the most serious long-term threat to the integrity of the Soviet state".

In summary, the first news article delivers three main messages:

1) Nationalism as a threat to the integrity of the Soviet State;

\footnotetext{
${ }^{223}$ P.Taubman, Soviet Reports Major Unrest in Armenian Areas in South, "New York Times", 24.02.1988, p. A1.

${ }^{224}$ Ibidem, p. A1.

${ }^{225}$ Ibidem, p. A1.
} 
2) Religious differences between Armenians and Azerbaijanis; and

3) Emigration associating Armenians with Jews and Germans, and binding them with brethren communities in the United States.

These messages serve as a reference point for the second article whose title, "A Dispute with Religious Overtones", clearly speaks for itself. The article's lead focuses the readers' attention on the religious aspect of the conflict, in the spirit of comparing "the ancient scars of geology with most recent scars of Islamic-Christian friction", or facing "a center of Orthodox Armenia" with "the predominantly Moslem republic of Azerbaijan".

"The southern rim of the Soviet Transcaucasia, the focal point of recent nationalist demonstrations, is an arid mountainous region crisscrossed by ancient scars of geology and the more recent scars of Islamic-Christian friction"...

..."The region of Nagorno-Karabakh, whose official governing council has unsuccessfully petitioned for the reunification with Armenia, is one of two disputed areas that have long been the focus of tension between Armenia, a center of Orthodox Christianity, and the adjoining, predominantly Moslem republic of Azerbaijan". 226

The author clearly remarks two points: 1) Armenia as a center of Orthodox Christianity versus Azerbaijan, a predominantly Moslem Republic; and 2) Nagorno-Karabakh as one of the two disputed areas.

Another interesting point is the purely academic determination of location, "the southern rim of Soviet Transcaucasia". Apparently, when the restive region of NagornoKarabakh came into sight, Western journalists were taken by surprise, for they were not wellprepared for such emergency. Due to the travel ban to the conflict zone, they did not have direct access to the information from any witnesses at the scene. To counterbalance that shortcoming and, consequently, close the information gap on the history of the region the conflict it was getting increasingly plunged in, the author turns to Richard Gable Hovannisian, an Armenian American historian and professor of Armenian and Near Eastern history at the University of California. According to the professor: "That region and two others, Nakhchevansky and Zangezur, was ceded to Armenia by Azerbaijan when Armenia became a part of the Soviet Union in December 1920. But the Islamic Turks to Armenia's west opposed the enhancement of Armenian territory at the expense of the Islamic Azerbaijanis to the east.

Because of Stalin and other Soviet leaders needed Turkey's influence to help bring the Moslem central Asian regions under Soviet control, Turkish preferences in the Transcaucauses were eventually heeded.

In 1924, Nakhichevansky and Nagorno-Karabakh, which historically was known for its silk industry, were put under Azerbaijani control". 227

The opinion and respective conclusions, which were cited with reference to the professor, produced a number of ambivalent and dubious judgments for a wide audience without any knowledge of the aforementioned historical events. Although Mr Hovannisian stated that territorial disputes were solved in 1924, the case of Karabakh was considered and decided on by the Transcaucasian Bureau of Central Committee of the Communist Party, in the course of the corresponding plenary session that was conducted since the $4^{\text {th }}$ through the

\footnotetext{
${ }^{226}$ F. Barringer, A Dispute with Religious Overtones, "New York Times", 24.02.1988, p. A15.

${ }^{227}$ Ibidem, p. A15.
} 
$5^{\text {th }}$ of July 1921. The decision stated: "Proceeding from the need for inter-ethnic peace between the Muslims and Armenians, and economic ties between the upper and lower Karabakh, its constant connection with Azerbaijan, leave Nagorno-Karabakh within Azerbaijan SSR, granting it a broad regional autonomy, with Shusha town, included in the autonomous region, to be a seat of regional administration." 228 The fate of Nakhchivan was sealed on the $13^{\text {th }}$ of October 1921, with the Treaty of Kars that was signed by the representatives from Turkey, as well as Armenian, Azerbaijan and Georgian Soviet Republics, with the participation of the Russian SFSR. ${ }^{229}$

Being an elite newspaper, the NYT is supposed to distinguish itself in publishing accurate, balanced and unbiased coverage of events. Usually unbalanced or biased coverage of a topic, or presentation of inaccurate information prompts the newspaper to make corrections following revision by the editorial staff or the letter(s) written by the reader(s) to the editor. With regard to Mr Hovanissian's falsification of history, neither the NYT editorial staff nor the readers reacted. This fact and the analysis of the two first articles about the conflict have revealed the main finding: due to the shortage of information and a travel ban to the region, foreign journalists were under a handicap to get information from the primary source and totally depended on external sources. Such dependence caused a vicious circle: lack of alternative sources of information led to the violation of journalism standards, and subsequently developed into respective one-sided coverage. Furthermore, one-sided news presented an unbalanced approach based upon willingness of privileged sources to initially cover the real root cause behind the conflict with the 'mask' of Christian-Moslem confrontation. The analysis of the aforementioned articles shows that having cut off from the primary source(s) and influenced by the scarcity of news produced by a handful of media outlets, NYT slowly, but surely started to incline towards religious dimensions of the conflict.

Meanwhile, the analysis of information sources for the 140 articles published in 1988 reveals that the Armenian sources were referred to far more frequently than the Azerbaijani sources, in the ratio of four to one. The Azerbaijani sources were mainly official news agencies, and the officials themselves. Only twice could Azerbaijani academician Z.

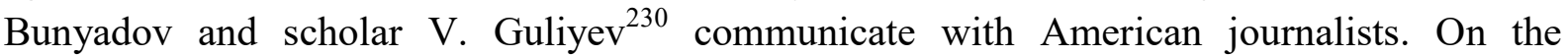
contrary, Armenian sources were more diverse, including even "one a Muscovite, who said to be in touch with residents of Stepanakert, dissidents, who are not always reliable sources of information", ${ }^{231}$ a telephone operator from Soviet Armenia, church sources in Armenia, Armenian religious leaders in America. ${ }^{232}$ These sources were seeking the journalists themselves and actively provided them with the news even from Stepanakert [now Khankendi - A.B.].

\footnotetext{
${ }^{228}$ История образования Нагорно-Карабахской Автономной Области Азербайджанской ССР. 1918-1925: Документы и материалы. Баку 1989, стр. 58-59.

${ }^{229}$ Ю.Г.Барсегов, Геноцид армян. Ответственность Турции и обязательства мирового сообщества, том 2 , часть 1. Москва 2003, стр. 557.

${ }^{230}$ F. Barringer, Behind the Armenian crisis, rising expactations and old enmities, "New York Times", 11.03.1988, p. A1.

${ }^{231}$ P.Taubman, News Cut Off as Armenain Protests Continue, "New York Times", 26.02.1988, p. A6.

${ }^{232}$ For Armenian in US., an Issue of Solidarity. "New York Times", 27.02.1988, p. A6.
} 
A religious dimension was taken on for very long and contributed to shaping the angle at which the news reporting was framed and its background was formulated. In news reporting, the background information plays an important role to understand the topic. As the name suggests, background information means all information that the audience needs to increase their awareness of the topic to get the whole picture. The frequency of background information, particularly its repetition, is central to the formation of public opinion.

The analysis of background information for the articles, written by F. Taubman, a correspondent of the NYT Moscow service, in February 1988, unveils compelling facts about the messages, as well as their frequency to get across to the audience:

- "The demonstrations center on demands that the Nagorno-Karabakh Autonomous Region, a predominantly Armenian area within Azerbaijan, be attached to Armenia. Most Armenians are Christian, most Azerbaijanis Moslem". 233

- "The demonstrations center on demands that the Nagorno-Karabakh autonomous region, a predominantly Armenian area within Azerbaijan, be attached to Armenia. Most Armenians are Christian, most Azerbaijanis Moslem". ${ }^{234}$

- "The demonstrations center on demands that the Nagorno-Karabakh Autonomous Region, a predominantly Armenian area within Azerbaijan, be incorporated into Armenia. Most Armenians are Christian, most Azerbaijanis Moslem". ${ }^{235}$

It is not a mere repetition, for such frequency, aimed at delivering the main message as long as possible, turns out to be absolutely instrumental in shaping public opinion. Such approach once again proves what Walter Lippmann, an American writer and political commentator, circulated as the theory of stereotypes and the role of permanent and continuous messages in shaping images.

The messages based on the religious character of the conflict, defined in the framing of the first articles, were developed throughout 1988.

Since March, NYT enhanced the religious framing by adding new episodes out of the past. The paper started to allude to a history of hostility dating back more than a century.

"The events underscored the volatility of the situation in the Soviet Union's two southern republics, where the predominantly Moslem Azerbaijanis have a history of hostility dating back more than century". 236

In May the same approach was employed by B. Killer, another NYT correspondent: "The grievances fed on a long history of hostility between Armenians, who are predominantly Christian, and Azerbaijanis, who are heavily Moslem". ${ }^{237}$

In July, F. Barringer was back to the topic by using the same background - history of hostility.

"The predominantly Islamic people of Azerbaijanis and the predominantly Christian Armenians - two groups who have a history of hostility - both consider the mountainous area with its fertile valleys an economic and cultural heartland". 238

\footnotetext{
${ }^{233}$ P.Taubman, Soviet Trying to Quell Ethnic Unrest. "New York Times", 25.02.1988, p. A6.

${ }^{234}$ Eadem, News Cut off as Armenian Protests Continue, "New York Times", 26.02.1988, p. A6.

${ }^{235}$ Eadem, Gorbachev Urges Armenians to End Nationalist Furor, "New York Times", 27.02.1988, p.1.

${ }^{236}$ F.Barringer, Soviet Armenian Mourn Their Deads, "New York Times”, 09.03.1988, p.8.

${ }^{237}$ B.Killer, Soviet Dismisses Two Party Chiefs in Tense Republics, "New York Times", 22.05.1988, p.2.
} 
That approach remained unchanged in November:

"Animosity between Armenians, who are mostly Christian, and Azerbaijanis, mostly Moslem, dates back hundreds of years in the Transcaucasus region that now forms part of the Soviet border with Turkey and Iran". 239

In December, B. Keller added a new element, "a historically rooted bitterness".

"What began with street demonstrations and petitions grew into widespread civil disobedience as the Kremlin refused to comply with Armenian demands. Meanwhile, the dispute fed a volatile, historically rooted bitterness between the Christian Armenians and the predominantly Muslim Azerbaijanis'. ${ }^{240}$

Until December 1988, the newspaper developed the religious framing by means of additional negative elements. It went further and portrayed Azerbaijan not an ordinary Islamic country. On the $1^{\text {st }}$ of March, F.Taubman portrayed predominantly Muslim Azerbaijanis as primarily Shiite Muslim.

"The two groups are divided by religion - the Armenians primarily Christian, the Azerbaijanis primarily Shiite Moslem - and by a history of conflict predating the formation of the Soviet Union". 241

Two days later, on the $3^{\text {rd }}$ of March, more information on the Shiite topic appeared under the subtitle People in the NYT article "Azerbaijan at a Glance": "Well over half of the 6.7. million people living in the Azerbaijan Soviet Socialist Republic are Shiite Moslem". ${ }^{242}$

The aim of such approach is self-evident - to bring a new element to the religious framing to grab the audience's attention. With that point in view, the newspaper differentiated Sunni Muslims from their Shiite compatriots, explaining the threat of being a Shiite Muslim. Shortly afterwards, in the article "Gorbachev Is Feeling the Heat From the South", F. Taubman wrote:

"Most Soviet Moslems area members of the Sunni faith, which has generally been resistant to the fundamentalist movement and Moscow has worked hard over the decades - with some success - to make the "southern republics as secular as possible". 243

In his opinion: "One of the disquieting aspects of the recent disturbances for Moscow was the involvement of Azerbaijanis, who are predominantly Shiite Moslems, the sect has been most open to Islamic fundamentalism. The Soviet Azerbaijani population of 5.5 million is matched by an equal number of Azerbaijanis in the neighboring northwest corner of Iran, and Soviet officials have long been feared the spread f fundamentalism across the border". ${ }^{244}$

In addition to a sheer distortion of the number of Azerbaijanis in Iran, the newspaper repeatedly emphasized the role of religion in conflict resolution, outlining the possible

\footnotetext{
${ }^{238}$ F.Barringer, Armenians, Irate at Party Conference Results, Resume Wide Unrest, "New York Times", 06.07.1988, p. A6.

${ }^{239}$ P.Taubman, Soviet Army Puts Armenian Capital under its Control; Curbs on Ethnic Rivals Patrols, Curfews and Ban on Protests Imposed in Two Republics in the South Military Controls Armenian Capital, "New York Times", 26.11,1988, p.1.

${ }^{240}$ B. Keller, Armenia Opens to Show Capital Under Tight Lid; "New York Times", 22.12.1988, p. A1.

${ }^{241}$ P. Taubman, Unrest Appears Linked to Recent Nationalist Protests in the Region, "New York Times", 01.03.1988, p. A1.

242 Azerbaijan at Glance, "New York Times", 03.03.1988, p. A6.

${ }^{243}$ F.Taubman, Gorbachev Is Feeling the Heat From the South, "New York Times", 06.03.1988, p.E3.

${ }^{244}$ Ibidem, p.E3.
} 
scenario of events: "Nagorno-Karabakh has presented a thorny problem for the Communist Party in Moscow, which is clearly directing the search for a political settlement. To order Azerbaijan to surrender Nagorno-Karabakh would inflame passions in predominantly Islamic Azerbaijan and embolden nationalist protesters in other republics". ${ }^{245}$

To maneuver for position, the NYT held firm to a completely different approach, implying double standards existing with regards to the religious background of two nations. The church, Christianity, their role in society and in the life of Armenian people always presented from the positive viewpoint: "The Armenian Orthodox Church is a key ingredient in the social glue that binds the Armenians, here and abroad into a close-knit culture". ${ }^{246}$

The author underlined the fact that like the Russian Orthodox Church, Baptist and other denominations, the Armenian Apostolic Church operated under the regulation of the state, but most Armenian congregations, even those in the West, recognizes the primacy of the Armenian Patriarch, or Catholicos, based in Etchmiadzin. The newspaper provided extensive information about the Armenian Apostolic Church, its financial independence and undeniable role of the Catholicos in the relevant political events outside Armenia.

"The church has also been at the center of demonstrations by Armenian communities in Los Angeles, New York, and elsewhere and these protesters are believed to have the personal blessing of the Catholicos". 247

On one hand, the protesters from Armenian communities in Los Angeles, New York, and elsewhere were believed to have the personal blessing of the Catholicos, while on the other hand, the Catholicos on the $25^{\text {th }}$ of February appeared on the Armenian television and pronounced the population's demands "natural, legal and constitutional". He appealed for calm, and announced that he had sent Mr. Gorbachev a telegram urging him to support the territorial claim.

Throughout 1988, NYT religious framing of the conflict was accompanied by a positive image of the Armenian Apostolic Church versus hardline fundamentalism of the Shiite faith. A negative attitude towards Shiite Islam and its threats were also supported by the NYT audience.

Needless to say, American Armenians had a heavy hand in the religious framing of the Nagorno-Karabakh conflict. They benefited from the existing opportunities to approach journalists themselves. NYT's Add and Letter pages provided a good platform for American Armenians to promote their respective views on and defend their political reasoning behind the conflict. ${ }^{248}$

The authors of two letters on the grounds of the Nagorno-Karabakh conflict, which were addressed to the NYT in 1988, were American Armenians. They enhanced the religious framing feeding it with a new phrase, an "ever-increasing militancy of Islamic fundamentalism":

\footnotetext{
${ }^{245}$ B.Keller, Strike Ends in Armenia as Unrest Slows, "New York Times", 15.06.1988, p. A3.

${ }^{246}$ Eadem, Armenians Forsakes the Liturgy to Tend His Flock, "New York Times",17.03.1988, p. A4.

${ }^{247}$ B.Keller, Armenians Forsakes the Liturgy to Tend His Flock, "New York Times",17.03.1988, p. A4.

${ }^{248}$ Display AD 67- -No Title,Karabakh is Armenain, "New York Times”, 11.03.1988, p. D19.
} 
"Given the ever-increasing militancy of Islamic fundamentalism, the Kremlin may soon be faced with a majority of its people looking not to Moscow but to Mecca for their leadership. As it is, none of ranking of the Soviet Politburo are believed to be of Islamic background". ${ }^{249}$

Such religious framing in 1988 bolstered anti-Shiite and anti-Soviet sentiments in the West and did not undergo any changes during the years to come. Besides, the established framework snapped into further cementing both the unbalanced approach and reporting. Even though the NYT reported about massive killing of ethnic Azerbaijanis in Ararat and Gugark settlement of Armenia and the first victims in Azerbaijan - two young Azerbaijanis, Ali and Bakhtiyar $^{250}$, murdered in Agdam, a major provincial town in the lowland part of Karabakh that news never transformed into separate stories, and was never added to the conflict background information. Even the Khojaly massacre in 1992, which received broad coverage in the NYT, was later dropped from the news change, while the events in Sumgayit and Kirovabad [now Ganja - A.B.], portrayed as a pogrom, became an integral part of the news chain and translated into the main elements of the conflict background information.

Religious framing of the conflict was produced during pre-independence period, the years of political turmoil, when the U.S. kept a vigil eye on making the Soviet Union, another superpower, weaken. This framing was more and less instrumental in the first years of independence as well, when the policy on the South Caucasus was not elaborated. The year 1994 was crucial for the future of the region. Brokered in May, a ceasefire agreement, and a supervening production-sharing agreement on the development of energy resources in the Azerbaijani sector of the Caspian Sea ("Contract of the Century") set a new agenda with the new framing based on political realities, rather than speculations or attempts to cover territorial claims by means of religious and ethnic dimensions. Since independence Azerbaijan has developed into a secular state with rich multicultural heritage. Surprisingly, Armenia has forged a strong alliance with the Islamic Republic of Iran, a Shiite stronghold.

\section{Streszczenie:}

Niniejszy artykuł bada rolę gazet w rozwoju biegu historii, a w szczególności wkład zdigitalizowanych archiwów gazetowych w tworzenie historii. Badając relację z Konfliktu w Górskim Karabachu w Nowym Jorku, autor nawiązał do jakościowych i ilościowych metod rozwiązywania głównego pytania badawczego: w jakim stopniu archiwa gazetowe mogą przynieść korzyści w tworzeniu historii i jakie są zalety i wady takiego projektu dla historiografii? Analiza ponad 500 artykułów na temat konfliktu w Górskim Karabachu, które powstały w okresie przed uzyskaniem niepodległości w latach 1988-1991, ujawniła główny wniosek: sam brak informacji i zakaz podróżowania do strefy konfliktu uzależnił dziennikarzy od ograniczonych i tendencyjnych źródeł informacji, które były dostępne, kształtując w ten sposób niedokładne i niewyważone podejście w oparciu o ujęcie konfliktu z perspektywy religijnej. Takie podejście, odgrywające zasadniczą rolę $\mathrm{w}$ kształtowaniu mentalności narodów w okresie przed uzyskaniem niepodległości, miało swoje konsekwencje.

\footnotetext{
${ }^{249}$ R.H.Tembeckjian, Rise of Islam in Soviet Union Tests Gorbachov, "New York Times", 05.07.1988, p. A16.

${ }^{250}$ F. Barringer, Behind the Armenian crisis, rising expactations and old enmities, "New York Times", 11.03.1988, p. A1.
} 


\section{Słowa kluczowe:}

Konflikt w Górskim Karabachu, Kaukaz Południowy, Pierestrojka, okres przed niepodległością, ramy religijne

\section{Key words:}

Nagorno-Karabakh Conflict, South Caucasus, Perestroika, pre-independence period, religious framing.

\section{Bibliografia:}

1. Azerbaijan at Glance, "New York Times", 03.03.1988, p. A6.

2. B. Keller, Armenia Opens to Show Capital Under Tight Lid; "New York Times", 22.12.1988, p. A1.

3. B. Keller, Armenians Forsakes the Liturgy to Tend His Flock, "New York Times",17.03.1988, p. A4.

4. B. Killer, Soviet Dismisses Two Party Chiefs in Tense Republics, "NewYork Times", 22.05.1988, p.2.

5. B. Keller, Strike Ends in Armenia as Unrest Slows, "New York Times", 15.06.1988, p. A3.

6. Display AD 67--No Title,Karabakh is Armenain,"New York Times", 11.03.1988, p. D19.

7. F. Barringer, A Dispute with Religious Overtones, "New York Times", 24.02.1988, p. A15.

8. F. Barringer, Armenians, Irate at Party Conference Results, Resume Wide Unrest, "New York Times", 06.07.1988, p. A6.

9. F. Barringer, Behind the Armenian crisis, rising expactations and old enmities, "New York Times", 11.03.1988, p. A1.

10. F. Barringer, Soviet Armenian Mourn Their Deads, "New York Times", 09.03.1988, p.8.

11. For Armenian in US., an Issue of Solidarity. "New York Times", 27.02.1988, p. A6.

12. P. Taubman, News Cut Off as Armenain Protests Continue, "New York Times", 26.02.1988, p. A6.

13. P. Taubman, "Gorbachev Is Feeling the Heat From the South, "New York Times", 06.03.1988, p.E3.

14. P. Taubman, Gorbachev Urges Armenians to End Nationalist Furor, "New York Times", 27.02.1988, p.1.

15. P. Taubman, Soviet Army Puts Armenian Capital under its Control; Curbs on Ethnic Rivals Patrols, Curfews and Ban on Protests Imposed in Two Republics in the South Military Controls Armenian Capital,"New York Times", 26.11,1988, p.1.

16. P. Taubman, Soviet Reports Major Unrest in Armenian Areas in South, "New York Times", 24.02.1988, p. A1. 
17. P. Taubman, Soviet Trying to Quell Ethnic Unrest. "New York Times", 25.02.1988, p. A6.

18. P. Taubman, Unrest Appears Linked to Recent Nationalist Protests in the Region, "New York Times", 01.03.1988, p. A1.

19. R.H.Tembeckjian, Rise of Islam in Soviet Union Tests Gorbachov, "New York Times", 05.07.1988, p. A16.

20. Ю.Г. Барсегов, Геноцид армян. Ответственность Турции и обязательства мирового сообщества, том 2, часть 1. Москва 2003, стр. 557.

21. История образования Нагорно-Карабахской Автономной Области Азербайджанской ССР. 1918-1925: Документы и материалы. Баку 1989, стр. 5859. 